\title{
Developmental accumulation of lectin in Rhizoctonia solani: a potential role as a storage protein
}

\author{
Jan T. C. Kellens* and Willy J. Peumans \\ Katholieke Universiteit Leuven, Laboratorium voor Fytopathologie en Plantenbescherming, Fakulteit der \\ Landbouwwetenschappen, Willem de Croylaan 42, B-3030 Leuven, Belgium
}

(Received 17 April 1990; revised 24 August 1990; accepted 29 August 1990)

\begin{abstract}
The lectin in Rhizoctonia solani is a major protein, although its function was previously unknown. An enzymelinked immunosorbent assay was developed to quantify the lectin content in mycelium, sclerotia and culture filtrate during the development of $\boldsymbol{R}$. solani grown in a synthetic medium. Lectin content was low in young mycelium but increased dramatically at the onset of sclerotium formation, reaching a maximum in adult sclerotia. Upon myceliogenic germination, the lectin content of the sclerotia rapidly decreased. It thus appears that the lectin is a developmentally regulated sclerotium-specific protein accumulating during sclerotium formation and disappearing during germination. Its relative abundance and the pattern of developmental control suggests that the lectin is probably a storage protein. Lectin accumulation was also influenced by the composition of the medium. Addition of supplementary carbohydrate (D-glucose) caused a marked reduction in lectin content whereas increased nitrogen in the form of $\mathrm{L}$-asparagine led to a higher lectin content. However, when the $\mathrm{L}$-asparagine concentration was too high, autolysis occurred and part of the lectin was released into the medium.
\end{abstract}

\section{Introduction}

During the last decade, numerous lectins have been isolated and characterized from mushrooms and other fungi. However, the physiological role(s) of most fungal lectins is still unclear and speculative. In Neurospora sitophila the lectin is thought to play an important role in cell wall biosynthesis and mycelial differentiation (Ishikawa \& Oishi, 1989). Others have postulated that fungal lectins are involved in adhesion and recognition phenomena. In Saccharomyces cerevisiae the mating interaction is mediated by agglutinins (Terrance et al., 1987) whereas in lichens, fungal lectins are involved in the relationship between the fungal and algal components (Lockhart et al., 1978). Adhesion by lectins may also be the initial step in certain infection processes. Thus, the exocellular lectins on the spores of the entomopathogenic fungus Conidiobolus obscurus are believed to mediate in the adhesion of fungal spores to their host insect (Latgé et al., 1988) and the lectins on the trap surface of many nematode-trapping fungi are important in the attachment of those fungi to nematodes (Nordbring-Hertz \& Mattiasson, 1979; Rosenzweig et al., 1985). In contrast, lectins from the soil-borne plant-

Abbreviation: RSA, Rhizoctonia solani agglutinin. pathogenic fungi Sclerotium rolfsii and Rhizoctonia solani are believed to play a role in the specific recognition of these fungi by the mycoparasite Trichoderma. The agglutinin of Sclerotium rolfsii is secreted into the growth medium and seems to be firmly associated with the extracellular polysaccharide, whereas the L-fucose-binding lectin of $R$. solani is associated with the cell wall (Barak et al., 1985, 1986). Recently another $R$. solani lectin has been isolated and characterized in our laboratory. It is a soluble intracellular protein exhibiting specificity towards $\mathrm{N}$-acetylgalactosamine and several other simple sugars and accounts for $11 \%$ of the total protein (Vranken et al., 1987). Until now, however, nothing has been known about the physiological role of this lectin, although its relative abundance suggested that it is possibly a storage protein.

In the present study we report a detailed analysis of the accumulation and distribution of the $R$. solani agglutinin (RSA) in the mycelium and the sclerotia, and present evidence for the influence of both D-glucose and Lasparagine concentration on lectin accumulation.

\section{Methods}

Organism and growth conditions. Rhizoctonia solani Kühn (isolate CBS 207.84) was obtained from the Centraalbureau voor Schimmelcultures, Baarn, the Netherlands, and cultured in a synthetic liquid medium 
containing (per litre distilled water) $\mathrm{L}$-asparagine, $2.0 \mathrm{~g}$ (unless stated otherwise); D-glucose, $15.0 \mathrm{~g}$ (unless stated otherwise); $\mathrm{KH}_{2} \mathrm{PO}_{4}, 1.4 \mathrm{~g}$; $\mathrm{MgSO}_{4} .7 \mathrm{H}_{2} \mathrm{O}, 1.0 \mathrm{~g} ; \mathrm{ZnSO}_{4} .7 \mathrm{H}_{2} \mathrm{O}, 4.4 \mathrm{mg} ; \mathrm{FeSO}_{4} .7 \mathrm{H}_{2} \mathrm{O}, 1.0 \mathrm{mg}$; $\mathrm{MnCl}_{2} .4 \mathrm{H}_{2} \mathrm{O}, 86 \mu \mathrm{g} ; \mathrm{CuSO}_{4} .5 \mathrm{H}_{2} \mathrm{O}, 79 \mu \mathrm{g}$; and $\mathrm{Na}_{2} \mathrm{MoO}_{4} \cdot 2 \mathrm{H}_{2} \mathrm{O}$, $53 \mu \mathrm{g}$ (pH 5.2) (all chemicals were from UCB, Leuven, Belgium). The medium was autoclaved at $121^{\circ} \mathrm{C}$ for $20 \mathrm{~min}$, and after cooling at room temperature, $100 \mu \mathrm{l}$ per litre of a filter-sterilized (Acrodisc, Gelman Sciences, $0 \cdot 2 \mu \mathrm{m})$ solution of thiamin hydrochloride $\left(10 \mathrm{mg} \mathrm{ml}^{-1}\right)$ was added. The fungus was grown in $100 \mathrm{ml}$ Erlenmeyer flasks, each containing $30 \mathrm{ml}$ medium, at $27^{\circ} \mathrm{C}$ in static culture. Agar discs $(5 \mathrm{~mm}$ diameter) covered with mycelium were cut from 5-d-old cultures grown at $27^{\circ} \mathrm{C}$ on PDA (potato dextrose agar) and used as inocula. Every 2 or $3 \mathrm{~d}$ the contents of three Erlenmeyer flasks were sampled separately. Fungal mycelia were harvested on tared filter paper, lyophilized and dry weights determined. Mycelia and samples of culture filtrates were stored at $-20^{\circ} \mathrm{C}$ until further use.

To detect possible changes in RSA content during germination, adult sclerotia (of approximately the same size and age) were incubated in Petri dishes $(9 \mathrm{~cm}$ in diameter) containing $20 \mathrm{ml} 2 \%$ (w/v) agar at $27^{\circ} \mathrm{C}$. Every other day, the sclerotia were transferred to fresh Petri dishes containing the same medium, leaving behind the mycelium (in order to exhaust the sclerotia). The density of sclerotia was 20 per Petri dish throughout the experiments. Samples of 50 sclerotia (collected from 10 different Petri dishes) were taken every other day, lyophilized and stored at $-20^{\circ} \mathrm{C}$ until further use.

To determine the effect of nutrition on total protein and lectin contents of adult sclerotia, Petri dishes $(9 \mathrm{~cm}$ diameter) each containing $20 \mathrm{ml}$ medium in $2 \%(\mathrm{w} / \mathrm{v})$ agar with $15 \mathrm{~g} \mathrm{D}$-glucose $\mathrm{l}^{-1}$ and different concentrations of $\mathrm{L}$-asparagine $\left(0 \cdot 5,2 ; 4,7\right.$ or $\left.10 \mathrm{~g} \mathrm{l}^{-1}\right)$, and with $2 \mathrm{~g} \mathrm{~L}$ asparagine $1^{-1}$ and different concentrations of D-glucose $(5,10,15$ or $\left.25 \mathrm{~g} \mathrm{l}^{-1}\right)$, were : noculated with an agar disc ( $5 \mathrm{~mm}$ diameter) covered with mycelium of $R$. solani. Five Petri dishes of each medium were taken. After $25 \mathrm{~d}$, sclerotia were sampled from each dish with forceps, lyophilized, weighed and stored at $-20^{\circ} \mathrm{C}$ until further use.

Extraction and purification procedure. Samples were powdered in liquid nitrogen using a mortar and pestle and extracted with 50 vols (v/w) of PBS [phosphate-buffered saline: $1.5 \mathrm{~mm}-\mathrm{KH}_{2} \mathrm{PO}_{4} / 10 \mathrm{~mm}$ $\mathrm{Na}_{2} \mathrm{HPO}_{4}(\mathrm{pH} 7 \cdot 4), 3 \mathrm{mM}-\mathrm{KCl}, 140 \mathrm{mM}-\mathrm{NaCl}$ ]. Samples of 50 germinated sclerotia were extracted in $1 \mathrm{ml}$ PBS. A drop of extract was examined microscopically for lysis of fungal cells. Extracts were then centrifuged at $12000 \mathrm{~g}$ for $3 \mathrm{~min}$ and the supernatant removed with a Pasteur pipette. Extracts were used immediately or frozen at $-20^{\circ} \mathrm{C}$. RSA was purified according to Vranken et al. (1987) by affinity chromatography on immobilized gum arabic followed by ion-exchange chromatography on a Pharmacia Mono-S cation-exchange column using an FPLC system.

Immunization procedure. One milligram of highly purified RSA dissolved in $1 \mathrm{ml}$ PBS was emulsified in $1 \mathrm{ml}$ complete Freund's adjuvant and injected subcutaneously into a rabbit. Five booster injections were given at $10 \mathrm{~d}$ intervals. Ten days after the final injection, blood was removed from an ear marginal vein and allowed to clot overnight at room temperature. Crude antiserum was obtained by centrifugation at $3000 \mathrm{~g}$ for $5 \mathrm{~min}$.

Partial purification of crude antiserum. Crude antiserum was partially purified by repeated precipitation (six times) with $\left(\mathrm{NH}_{4}\right)_{2} \mathrm{SO}_{4}(40 \%$ relative saturation). The final precipitate was dissolved in $25 \mathrm{~mm}-$ Tris/ $\mathrm{HCl}(\mathrm{pH} 8 \cdot 7$ ) containing $0 \cdot 1 \mathrm{M}-\mathrm{NaCl}$ and dialysed for $3 \mathrm{~h}$ and then overnight against the same buffer. This fraction of the serum was then applied to an anion-exchange column $(25 \mathrm{~cm} \times 3 \mathrm{~cm})$ of Q-Fast Flow (Pharmacia), equilibrated with the same Tris buffer. Under these conditions, IgG immunoglobulins do not bind to the column and elute in a large peak just behind the void volume. This IgG fraction was collected and used in all further experiments.
Preparation of enzyme-labelled antibodies. Alkaline-phosphataseconjugated rabbit anti-RSA antibodies were prepared following the procedure of Voller et al. (1980), using glutaraldehyde to couple the enzyme to the antibody. Alkaline phosphatase (type VII-N from bovine intestinal mucosa) was purchased from Sigma.

Quantification of RSA in crude extracts by an enzyme-linked immunosorbent assay (ELISA). The lectin concentration of fungal extracts and culture filtrates was determined by developing a doublesandwich ELISA based on the specific binding of the lectin to antiRSA serum coupled to the titreplate and the recognition of the bound RSA by a second alkaline-phosphatase-conjugated anti-RSA serum. In this assay the amount of RSA is proportional to the concentration of the yellow reaction product which arises from the reaction of alkaline phosphatase with $p$-nitrophenyl phosphate. On each plate eight standards of known amounts of purified RSA were included. Eight twofold dilutions of each extract were pipetted. The lectin concentration in the extracts was calculated by linear regression. Flat-bottomed polyvinyl chloride microtitre plates ( 96 wells; Costar) were coated with $50 \mu \mathrm{l}$ per well of a $0.0002 \%(\mathrm{w} / \mathrm{v})$ solution of partially purified rabbit anti-RSA in borate/saline buffer $\left(6.19 \mathrm{~g} \mathrm{H}_{3} \mathrm{BO}_{3}, 8.50 \mathrm{~g}\right.$ $\mathrm{Na}_{2} \mathrm{~B}_{4} \mathrm{O}_{7} \cdot 10 \mathrm{H}_{2} \mathrm{O}, 4 \cdot 39 \mathrm{~g} \mathrm{NaCl}, 1$ litre distilled water) $\mathrm{pH} 8 \cdot 4$, for $2 \mathrm{~h}$ at $37^{\circ} \mathrm{C}$. Plates were then washed twice with PBS containing $0.02 \%(\mathrm{w} / \mathrm{v})$ sodium azide and $0.05 \%(\mathrm{v} / \mathrm{v})$ Tween 20 (PBST) and twice with PBS containing $0.02 \%(w / v)$ sodium azide alone (PBSN). To block the remaining nonspecific protein-binding sites, the wells were filled for $30 \mathrm{~min}$ at room temperature with $60 \mu \mathrm{l}$ borate/saline buffer containing $1 \%(\mathrm{w} / \mathrm{v})$ bovine serum albumin and $0.02 \%(\mathrm{w} / \mathrm{v})$ sodium azide. After washing twice with PBSN, different dilutions of fungal extracts and standard solutions of known concentrations of purified RSA, both in dilution buffer (PBST containing $1 \%, \mathrm{w} / \mathrm{v}$, bovine serum albumin and $100 \mathrm{mM}$-D-galactose), were incubated for $2 \mathrm{~h}$ at $37^{\circ} \mathrm{C}(50 \mu \mathrm{l}$ per well). Thereafter, the plates were washed twice with PBST and twice with PBSN. Then, $50 \mu 11 \%(\mathrm{v} / \mathrm{v})$ alkaline-phosphatase-conjugated antiRSA antibodies in dilution buffer was added to each well and the plates were incubated at $37^{\circ} \mathrm{C}$ for $2 \mathrm{~h}$. Unbound conjugate was washed away by rinsing the plates twice with PBST and twice with PBSN. The enzymic reaction was performed in $50 \mu \mathrm{l}$ per well of diethanolamine buffer $\left[9.6 \%(\mathrm{v} / \mathrm{v})\right.$ diethanolamine $\mathrm{pH} 9 \cdot 8,0.005 \%(\mathrm{w} / \mathrm{v}) \mathrm{MgCl}_{2}, 0.1 \%$ (w/v) p-nitrophenyl phosphate (Sigma)]. After approximately $30 \mathrm{~min}$ at room temperature the reaction was stopped by the addition of $4 \mathrm{M}$ $\mathrm{KOH}(50 \mu \mathrm{l}$ per well) and quantified by measuring the absorbance of the yellow reaction product at $405 \mathrm{~nm}$ using an SLT Easy Reader EAR 340 AT (SLT Labinstruments, Salzburg, Austria). Concentrations of purified RSA over the range $1-20 \mathrm{ng}$ per ml dilution buffer were used to prepare standard curves. Dilution buffer alone was used as a blank.

SDS-PAGE and Western blotting. The specificity of the antibodies was confirmed by SDS-PAGE on $6-20 \%(\mathrm{w} / \mathrm{v})$ polyacrylamide gradient gels using a discontinuous system (Laemmli, 1970), followed by electroblotting (Kyhse-Anderson, 1988). After blotting, the nitrocellulose filter was incubated for $30 \mathrm{~min}$ at room temperature with TBS

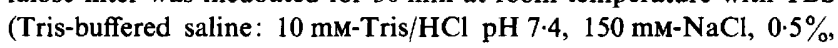
$\mathrm{w} / \mathrm{v}$, casein). Partially purified rabbit anti-RSA antibodies. $1 \%(\mathrm{v} / \mathrm{v})$ in TBS, were then added and incubation continued for $1 \mathrm{~h}$ at room temperature. After thorough washing with TBS, the nitrocellulose filter was incubated for $1 \mathrm{~h}$ at room temperature with $2 \%(\mathrm{v} / \mathrm{v})$ peroxidaseconjugated swine anti-rabbit immunoglobulins in TBS. Again the filter was thoroughly washed with TBS and the substrate $(0.05 \%$, w/v, 3,3'diaminobenzidine in $50 \mathrm{mM}-\mathrm{Tris} / \mathrm{HCl} \mathrm{pH} 7.4$ containing $0.03 \%(\mathrm{v} / \mathrm{v})$ $\mathrm{H}_{2} \mathrm{O}_{2}$ ) added. After $5 \mathrm{~min}$, the reaction was stopped by washing the nitrocellulose filter with distilled water.

Protein assay. Total protein was estimated by the Bio-Rad protein assay (Bio-Rad Laboratories) using bovine serum albumin and RSA $(1: 1, w / w)$ as standard. 


\section{Results and Discussion}

\section{Specificity of antibodies}

Highly purified lectin $(10 \mu \mathrm{g})$, a total protein extract from $R$. solani $(100 \mu \mathrm{g}$ protein) in $50 \mathrm{~mm}-\mathrm{Tris} / \mathrm{HCl}$ (pH 7.8) and the same extract (100 $\mu$ g protein) previously passed through a column of immobilized gum arabic (to remove the lectin) were analysed by SDS-PAGE followed by immunoblotting and reaction with the partially purified anti-RSA serum. In the crude extract, only the RSA polypeptide reacted with the antiserum, thereby indicating that the antiserum is monospecific (Fig. 1).

\section{Production and distribution of $R S A$ during fungal development}

After inoculation, the mycelium grew radially and formed a mat that covered the surface of the culture after approximately $5 \mathrm{~d}$. Sclerotia then began to develop as white tufts which became darkly pigmented after a few days. As shown in Fig. 2, the dry weight of the culture increased rapidly during the first $10 \mathrm{~d}$ and then decreased slightly. Marked increases in total protein and lectin content were also observed after $14 \mathrm{~d}$ and $7 \mathrm{~d}$, respectively.

To determine if the lectin accumulated in the sclerotia only or also in the old mycelium, mycelial mats were

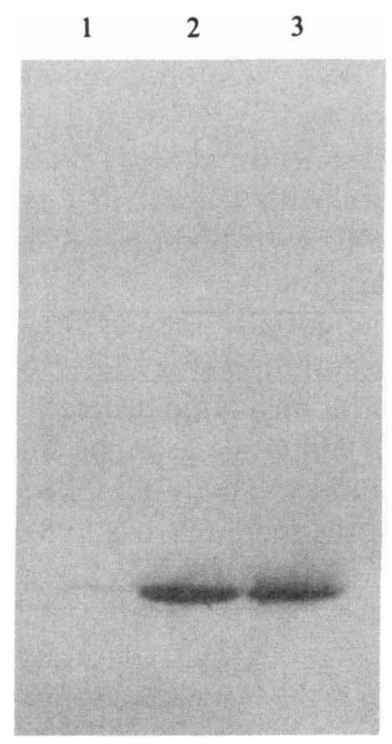

Fig. 1. Western blot of fungal extract and purified RSA. Purified RSA (3), a total extract from $R$. solani (2) and the same extract depleted of lectin by affinity chromatography (1) were analysed by SDS-PAGE followed by immunoblotting and reaction with purified anti-RSA serum.

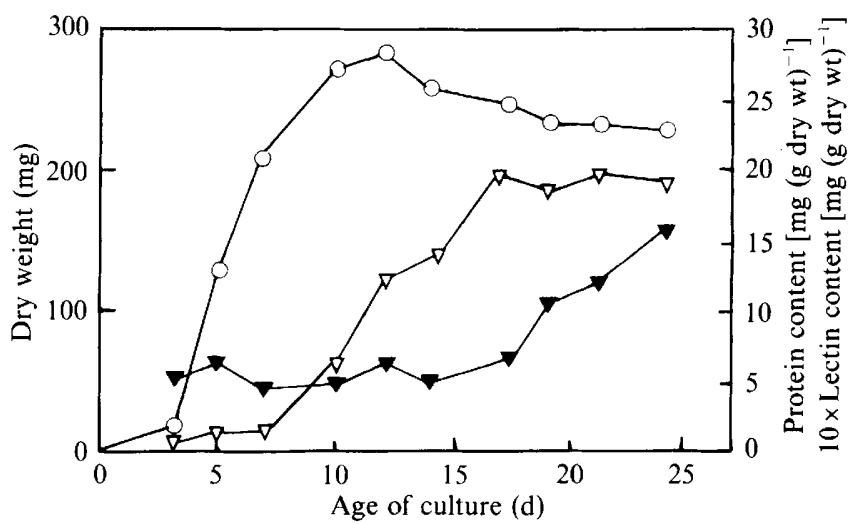

Fig. 2. Occurrence of RSA during fungal development. $R$. solani was cultured in a medium with $2 \mathrm{~g} \mathrm{~L}$-asparagine $1^{-1}$ and $15 \mathrm{~g} \mathrm{D}$-glucose $\mathrm{l}^{-1}$. At different stages, dry weight $(O)$, protein $(\nabla)$ and lectin content $(\nabla)$ were determined. Values represent the mean of three samples (variation about the mean was $<15 \%$ ).

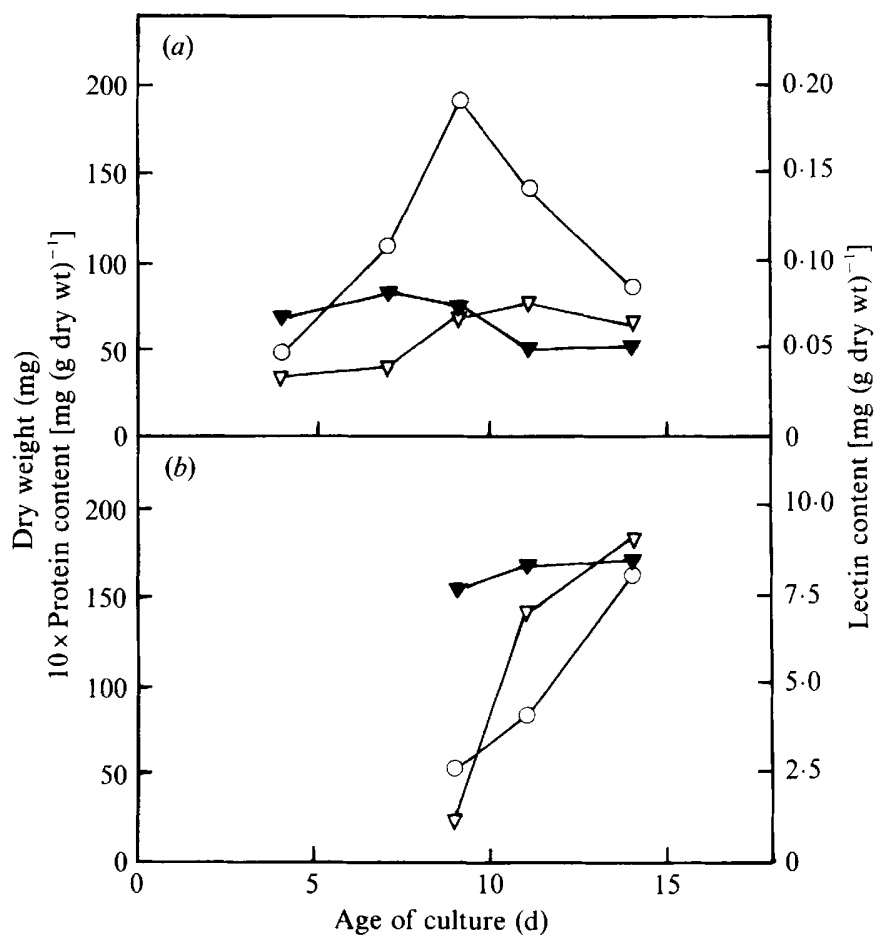

Fig. 3. Distribution of RSA in mycelium and sclerotia. $R$. solani was

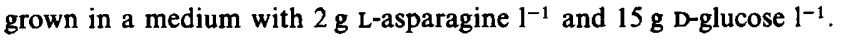
Every second or third day the mycelial mats of three flasks were harvested and the sclerotia separated with forceps. Dry weight $(O)$, protein $(\nabla)$ and lectin content $(\nabla)$ of both mycelium $(a)$ and sclerotia (b) were determined. Mean values are presented (three determinations; variation about the mean was $<10 \%$ ).

harvested every second or third day and the sclerotia separated with forceps. Dry weight, protein content and lectin content from mycelium and sclerotia were deter-mined separately (Fig. 3). The lectin content of sclerotia 


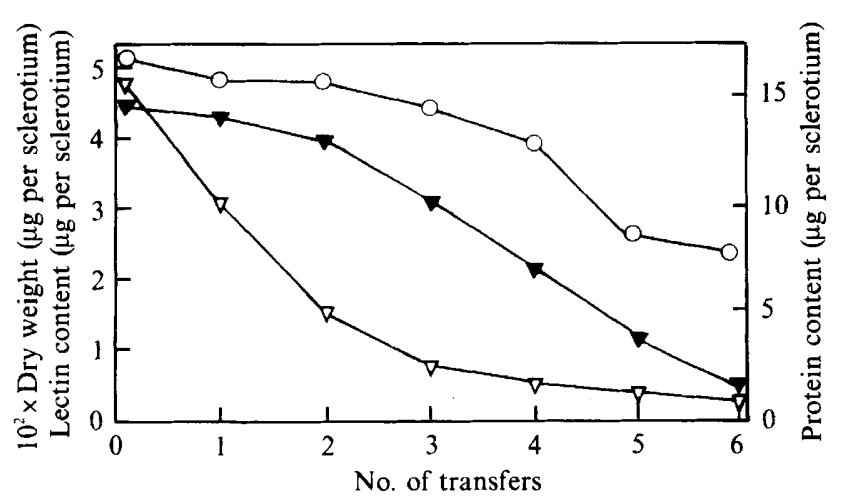

Fig. 4. Lectin and protein content of germinating sclerotia. Adult sclerotia were transferred several times onto water agar. Samples of 50 sclerotia were taken every other day and their dry weight $(O)$, protein $(\nabla)$ and lectin content $(\nabla)$ determined.

increased during maturation, to more than 100 times the amounts found in corresponding samples of mycelium, where levels remained relatively low and constant (Fig. 3). Total protein levels in both mycelia and sclerotia fluctuated less, although protein concentrations in adult sclerotia from 14-d-old cultures were approximately three times higher than those in mycelium (Fig. 3). Eventually, the lectin comprised up to $40 \%$ of the total sclerotial protein, which indicates that the lectin accumulated specifically in the sclerotia during their maturation. Until recently sclerotia were thought to contain mostly carbohydrates and lipids as storage compounds (Chet et al., 1969; Bullock et al., 1980). However, since large amounts of proteins have been found in sclerotia of Sclerotinia minor and Sclerotinia trifoliorum (Petersen et al., 1982), and of Sclerotium rolfsii and Botrytis cinerea (Insell et al., 1985) their role as storage proteins in these resting structures becomes apparent.

\section{Changes in the RSA content of sclerotia as a function of myceliogenic germination}

As shown in Fig. 4, the RSA content decreased at a much higher rate than the total protein content during successive rounds of myceliogenic germinations (producing only vegetative mycelia) on water agar. To ensure that no significant loss of RSA occurred by diffusion into the agar or transport to the developing mycelium, agar and mycelium was also extracted with PBS and the lectin content determined. Since no lectin could be detected in the medium or mycelium, the most likely conclusion is that the lectin is metabolized during myceliogenic germination of the sclerotia. Our findings are not in complete agreement with the results of Russo et al. (1982), who found that sclerotia of Sclerotinia sclerotiorum contained large amounts of a major protein (comprising up to $40 \%$ of the total cellular protein), the concentration of which decreased dramatically only during carpogenic germination (production of sexual fruiting bodies and ascospores) and remained constant during myceliogenic germination.

\section{Effect of nutrition on growth and lectin content of $R$. solani in a liquid culture medium}

Since the availability of exogenous nutrients is important for growth, differentiation, sporulation and virulence of fungal pathogens, it was of interest to determine the effect of nutrition on lectin accumulation in $R$. solani. Therefore, the fungus was grown in a synthetic culture medium containing different concentrations of carbon (D-glucose) and nitrogen (L-asparagine) sources.

In a first set of experiments $R$. solani was grown in a medium containing $15 \mathrm{~g} \mathrm{D}$-glucose $1^{-1}$ but different levels of L-asparagine $\left(0 \cdot 5,2,4,7\right.$ or $\left.10 \mathrm{~g}^{-1}\right)$. Every second or third day samples were taken and analysed as described in Methods. As shown in Fig. 5(b), the concentration of L-asparagine strongly affected the lectin content. Highest amounts of RSA were observed at an L-asparagine concentration of $4 \mathrm{~g} \mathrm{l}^{-1}$; below and above this optimal concentration, the lectin content was lower. The same pattern was seen with respect to total soluble protein content (Fig. $5 c$ ), with highest values again obtained with $4 \mathrm{~g}$ L-asparagine $\mathrm{l}^{-1}$.

Dry weight values also increased as a function of $L-$ asparagine concentration (Fig. 5a). However, above the optimal concentration a rapid decrease in dry weight was observed which cannot be ascribed solely to respiration but is probably due to autolysis. Indeed, as seen in Fig. $5(d)$, the $\mathrm{pH}$ of the medium rose to 8.0 in samples with

Fig. 5. Effect of L-asparagine concentration on growth and lectin content. $R$. solani was grown in a medium containing $15 \mathrm{~g} \mathrm{D}^{\mathrm{D} g l u c o s e} \mathrm{l}^{-1}$ and different concentrations of L-asparagine: $0.5(O), 2(\odot), 4(\square), 7(\square)$ or $10(\nabla) \mathrm{g} \mathrm{l}^{-1}$. At different stages dry weight $(a)$, lectin $(b)$ and protein content $(c)$ of the culture and the $\mathrm{pH}(d)$ and lectin concentration $(e)$ of the medium were determined. Values represent the mean of three samples (variation about the mean was $<12 \%$ ).

Fig. 6. Effect of D-glucose concentration on growth and lectin content. $R$. solani was grown in a medium containing $2 \mathrm{~g} \mathrm{~L}$-asparagine $\mathrm{l}^{-1}$ and different concentrations of D-glucose: $5(\mathrm{O}), 10(\mathrm{O}), 15(\square)$ or $25(\mathbf{\square}) \mathrm{g} \mathrm{I}^{-1}$. Dry weight $(a)$, lectin $(b)$ and protein content $(c)$ of the culture and the $\mathrm{pH}(d)$ and lectin concentration $(e)$ of the medium were determined. Values represent the mean of three samples (variation about the mean was $<10 \%$ ). 

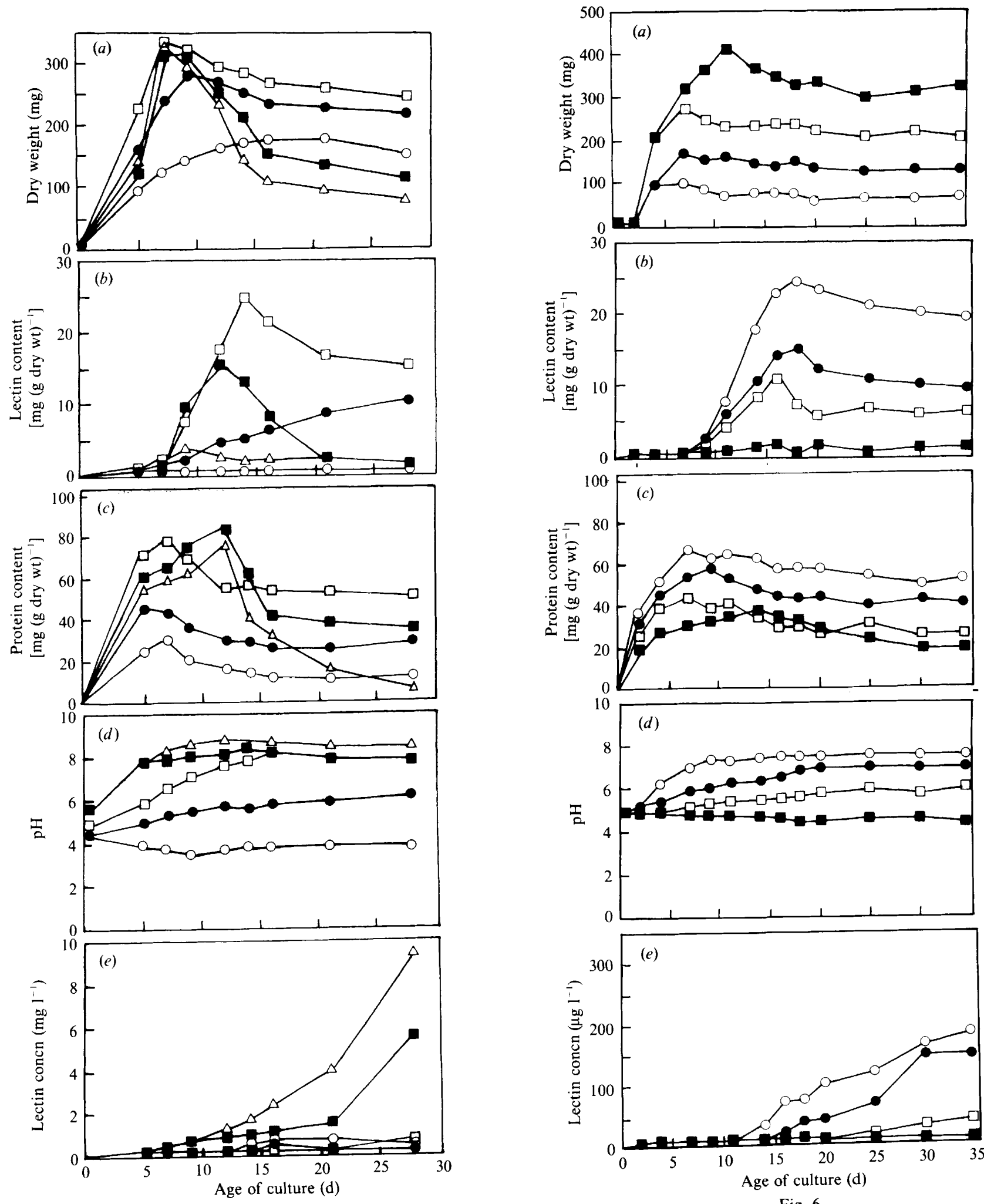

Fig. 5

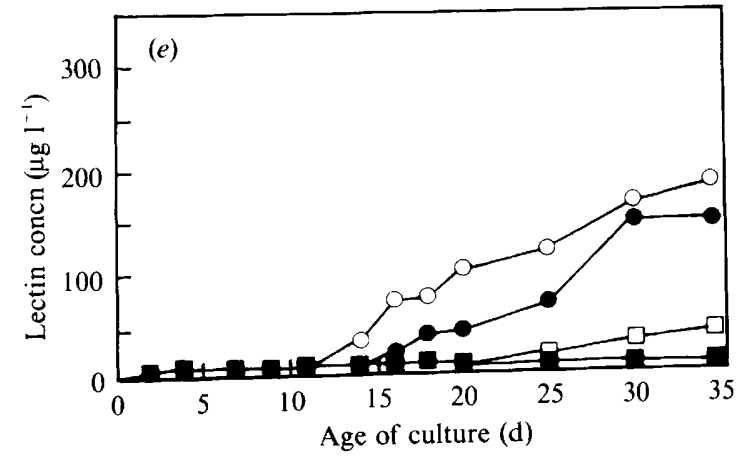

Fig. 6 
high L-asparagine concentrations. Most probably the fast growth of these cultures resulted in a rapid depletion of D-glucose so that energy had to be generated by the breakdown of $\mathrm{L}$-asparagine. During this process, large amounts of $\mathrm{NH}_{3}$ are liberated, causing a rise in $\mathrm{pH}$ and autolysis. Due to this autolysis, large amounts of RSA were found in the medium of cultures grown at high Lasparagine levels (Fig. 5e). Similar observations were recorded by Lahoz \& Miralles (1970), who found that when Aspergillus niger was grown under conditions of excess nitrogen and limited carbon source, the protein component of the cells was rapidly degraded.

As expected, when $R$. solani was grown in medium containing $2 \mathrm{~g} \mathrm{~L}$-asparagine $\mathrm{I}^{-1}$ and different concentrations of D-glucose $\left(5,10,15\right.$ or $\left.25 \mathrm{~g} \mathrm{l}^{-1}\right)$, the dry weight of the cultures increased as a function of D-glucose concentration (Fig. 6a). However, both the lectin and total protein content were highest in cultures containing the lowest D-glucose concentration (Fig. $6 b, c$ ). In these experiments, the $\mathrm{pH}$ of the medium increased only slightly (Fig. $6 d$ ); as a result no autolysis was observed and the lectin concentration in the medium remained low (Fig. 6e).

In a third set of experiments, the effect of both Lasparagine and D-glucose on the total protein and lectin accumulation was determined in sclerotia developing on a solid medium. As seen in Fig. 7(a), dry weight values were almost identical in the case of sclerotia from cultures containing $0.5,2$ or $4 \mathrm{~g} \mathrm{~L}$-asparagine $\mathrm{l}^{-1}$, but lectin and total protein contents differed markedly. The lectin content was highest in sclerotia formed in cultures with $4 \mathrm{~g}$ L-asparagine $1^{-1}$. In cultures with higher Lasparagine concentrations, no sclerotia were formed. In cultures containing high D-glucose concentrations, more sclerotia were formed but their protein and lectin contents were lower (Fig. 7 b). Formation of sclerotia is known to be influenced by nutrient conditions, and the maturation time for sclerotia of $R$. solani and Sclerotium rolfsii was closely related to the depletion of carbohydrates in the medium (Townsend, 1957). Nutrient deprivation might induce the formation of sclerotia from mycelial reserves and products of mycelial lysis (Christias \& Lockwood, 1973).

The high concentration of the $R$. solani lectin in the sclerotia, and its developmental regulation, indicate that it probably serves as a storage protein in the resting structures of this fungus. A similar storage role has been proposed for lectins which accumulate in the vegetative storage tissues of a number of plant species. Well-known examples of such plant lectins are the bark lectins of elderberry (Sambucus nigra) and black locust (Robinia pseudoacacia). Both lectins are bark-specific proteins which accumulate in large amounts at the end of the growing season (i.e. during autumn) and disappear when
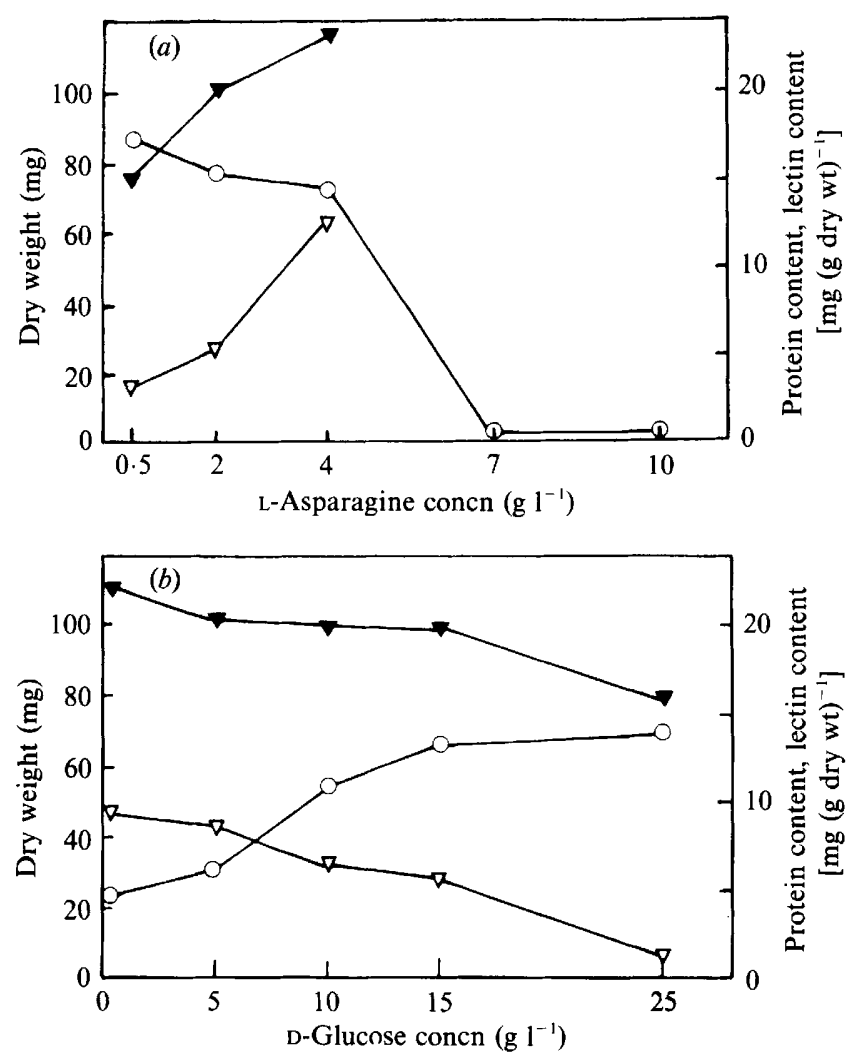

Fig. 7. Effect of L-asparagine (a) and D-glucose concentration (b) on sclerotium formation and lectin accumulation. $R$. solani was grown in Petri dishes containing agar media with $15 \mathrm{~g} \mathrm{D}$-glucose $\mathrm{l}^{-1}$ and different concentrations of L-asparagine (a) or $2 \mathrm{~g} \mathrm{~L}$-asparagine $\mathrm{l}^{-1}$ and different concentrations of D-glucose $(b)$. After $25 \mathrm{~d}$ sclerotia were collected with forceps, and their dry weight $(O)$, protein $(\nabla)$ and lectin content $(\nabla)$ determined. Dry weight is expressed as mg sclerotia per Petri dish.

new shoots emerge during spring (Peumans et al., 1986). Another example is the tulip lectin. This bulb specific protein accumulates in large quantities during the final stages of bulb formation and is degraded when new shoots emerge from the same bulbs (after a resting period) (Van Damme \& Peumans, 1989). Lectins in fungal sclerotia can, by analogy, be considered as storage proteins although this does not exclude the possibility that they also fulfil other roles.

This work was supported in part by grants from the Nationale Bank and the National Fund for Scientific Research (Belgium), of which W. J. Peumans is a Senior Research Associate. J. T. C. Kellens received a fellowship from the Belgian Instituut tot Aanmoediging van het Wetenschappelijk Onderzoek in Nijverheid en Landbouw.

\section{References}

BaraK, R., Elad, Y., Mirelman, D. \& Chet, I. (1985). Lectins: a possible basis for specific recognition in the interaction of Trichoderma and Sclerotium rolfsii. Phytopathology 75, 458-462. 
Barak, R., Elad, Y. \& CheT, I. (1986). The proterties of L-fucose binding agglutinin associated with the cell wall of Rhizoctonia solani. Archives of Microbiology 144, 346-349.

BulloCK, S., ASHFORD, A. E. \& WiLleTs, H. J. (1980). The structure and histochemistry of sclerotia of Sclerotinia minor Jagger. II. Histochemistry of extracellular substances and cytoplasmic reserves. Protoplasma 104, 333-351.

Chet, I., HeNIS, Y. \& KisLEV, N. (1969). Ultrastructure of sclerotia and hyphae of Sclerotium rolfsii Sacc. Journal of General Microbiology 57, 143-147.

Christias, C. \& Lockwood, J. L. (1973). Conservation of mycelial constituents in four sclerotium-forming fungi in nutrient-deprived conditions. Phytopathology 63, 602-605.

Insell, J. P., Huner, N. P. A., Newsted, W. J. \& Huystee, R. B. (1985). Light microscopic and polypeptide analysis of sclerotia from mesophilic and psychrophilic fungi. Canadian Journal of Botany 63, 2305-2310.

IshixaWA, F. \& OISHI, K. (1989). Production, purification and characterization of Neurospora sitophila lectin. Agricultural and Biological Chemistry 53, 1769-1776.

KYHSE-ANDERSON, J. (1988). Semi-dry electroblotting transfer using equipment without buffer vessels. In CRC Handbook of Immunoblotting, vol. 1, pp. 79-85. Edited by N. Heegard \& O. J. Bjerrum. Boca Raton, Florida: CRC Press.

LAEMMLI, U. K. (1970). Cleavage of structural proteins during the assembly of the head of bacteriophage T4. Nature, London 227, 680685.

LAHOZ, R. \& Miralles, M. (1970). Influence of the level of the carbon source on the autolysis of Aspergillus niger. Journal of General Microbiology 62, 271-276.

Latgé, J.-P., MonsignY, M. \& PREvost, M.-C. (1988). Visualization of exocellular lectins in the entomopathogenic fungus Conidiobolus obscurus. Journal of Histochemistry and Cytochemistry 36, 1419-1424.

Lockhart, C. M., Rowell, P. \& Stewart, W. D. P. (1978). Phytohaemagglutinin from TM nitrogen-fixing lichens Peltigera canina and Peltigera polydactyla. FEMS Microbiology Letters 3, 127130.
Nordbring-Hertz, B. \& Mattiasson, B. (1979). Action of a nematode-trapping fungus shows lectin-mediated host-microorganism interaction. Nature, London 281, 477-479.

Petersen, G. R., Russo, G. M. \& Van Etten, J. (1982). Identification of major proteins in sclerotia of Sclerotinia minor and Sclerotinia trifoliorum. Experimental Mycology 6, 268-273.

Peumans, W. J., Nsimba-Lubaki, M., Broekaert, W. F. \& Van DAMmE, E. J. M. (1986). Are bark lectins of elderberry (Sambucus nigra) and black locust (Robinia pseudoacacia) storage proteins? In Molecular Biology of Seed Storage Proteins and Lectins, pp. 53-63. Edited by L. M. Shannon \& M. J. Chrispeels. Baltimore, MD: Waverly Press.

Rosenzweig, W. D., Premachandran, D. \& Pramer, D. (1985). Role of trap lectins in the specificity of nematode capture by fungi. Canadian Journal of Microbiology 31, 693-695.

RUSSO, G. M., DAHLBERG, K. R. \& VAN ETTEN J. (1982). Identification of a development-specific protein in sclerotia of Sclerotinia sclerotiorum. Experimental Mycology 6, 259-267.

Terrance, K., Heller, P., Wu, Y.-S. \& Lipke, P. N. (1987). Identification of glycoprotein components of $\alpha$-agglutinin, a cell adhesion protein from Saccharomyces cerevisiae. Journal of Bacteriology 169, 475-482.

TowNSEND, B. B. (1957). Nutritional factors influencing the production of sclerotia by certain fungi. Annals of Botany 21, 153-166.

Van Damme, E. J. M. \& Peumans, W. J. (1989). Developmental changes and tissue distribution of lectin in Tulipa. Planta 178, 10-18.

Voller, A., Bidwell, D. \& Bartlett, A. (1980). Enzyme-linked immunosorbent assay. In Manual of Clinical Immunology, pp. 359371. Edited by N. R. Rose \& H. Friedman. Washington, DC: American Society for Microbiology.

Vranken, A. M., Van Damme, E. J. M., Allen, A. K. \& Peumans, W. J. (1987). Purification and properties of an $N$-acetylgalactosamine specific lectin from the plant pathogenic fungus Rhizoctonia solani. FEBS Letters 216, 67-72. 